\title{
二成層場および連続成層場における熱塩対流に関する研究 \\ THERMOSOLUTAL CONVECTION IN TWO-LAYERED AND CONTINUOUSLY STRATIFIED SYSTEMS COMPOSED OF HEAT-SALT COMPLEX
}

\author{
室 田 明*・道 奥 康 治** \\ By Akira MUROTA and Kohji MICHIOKU
}

\begin{abstract}
In order to study the mass transport process produced by the thermal convection, the thermosolutal convection in the two-layered and continuously stratified systems composed of heat-salt complex is investigated, experimentally and theoretically. Our preceding results, i.e. the stability criterion for the system with arbitrary distribution profiles of two density components and the evaluation of the diffusive and convective components of the heat-salt flux across the density interface, are introduced to develop the numerical model for the mixing process. The numerical results agrees well with the experimental data. In addition, the transforming process on the internal energy into the potential energy through the vertical mixing is quantitatively understood.
\end{abstract}

\section{1. 序論}

\section{（1）はじめに}

湖沼・貯水池の水質保全は利水システム運営上必須の 条件である.こうした停滞水域では移流と乱れの効果が 低減するため水温成層が発達し鉛直方向の運動を抑制し たり，逆に熱対流により鉛值混合が促進される等, 熱工 ネルギー収支が水質輸送に支配的な影響力をもつ.近年, 貯水池水温成層場を有限差分分割する数理モデルにより 生物的・化学的および物理的水質指標の動態を推分する 予測手法が確立されつつあるが移流効果に重点を置いた 解析が主体であり水表面熱収支や冷水塊の流入によって 生ずる熱対流混合過程を陽に考慮したものは数少ない.

熱対流がもたらす成層場での水質混合は 2 つの過程か ら成るといえよう. 1つは温度密度転倒による静的不安 定を解消する対流混合過程であり，もう1つは対流層と 周囲流体との間で生ずる連行過程である. 前者の場合, 対流層厚さや混合量は, 混合前後の熱量を保つように密 度転倒領域を等温度層に置換することによって容易に評 価される.これに対し後者の場合は対流運動が引き起こ

* 正会員 工博 大阪大学教授 工学部土木工学科 ( 5565 吹由沛山田近 2-1)

** 正会員 工修 大阪大学助手工学部土木工学科 (京上.)
す密度境界面での乱れ渦が混合の担い手であり, 連行量 は乱れ特性量を把握することによってのみ評価され得 る. しかしながら, 後者の過程は水質の鉛直輸送促進に 大きく貢献するにもかかわらず，現時点においてはそれ ほど多くの研究成果があるとはいいがたい。

そこで本研究では一様に混合した対流層と明瞭な界面 連行現象がともに観察される場として熱塩対流場を対象 とし, 熱と水質の輸送機構を基礎的に理解することを試 みる. 熱塩成層場においては熱と塩分濃度の抁散性の違 いから二重拡散現象とよばれる特有の挔散形態を呈する ことが知られている”。これは直接的には海洋微細構造 の形成や貯水池・湖沼の深層部での緩やかな鉛直混合に 貢献するといわれており ${ }^{2 !}$, 拡散係数の増大としてしか これまで評価されていなかった不明確な混合現象の実態 の一部を説明し得るものとして研究が積み重ねられてき た。一重拡散現象自体は熱と物質の拡散性が異なるこ と・物質濃度が密度差に寄与することなど特殊な条件を 必要亡し, 湖沼・貯水池の表面混合層内の熱対流によつ て生起する主躍層面での水質混合と直接相似するもので はないが, 対流の発生・対流層境界での乱れによる水質 混合過程, 熱エネルギーから物質輸送をもたらす仕事量 への変換過程等個々の基礎過程は実水域と相似な現象で あり,これらを把握することは水質輸送量を評価するう 
えできわめて重要であると考えられる.

\section{(2) 既往の研究}

熱対流による連行過程に重点を置き，しかも連行量の 定量評価を行った研究はきわめて数少ない. Deardorff ら $(1980)^{3)}$ は安定な水温成層を底面から加熱する実験 において, 対流層上端での連行 (Entrainment)・逆連 行過程 (Detrainment) の存在を確認し、これらが鉛直 混合に及ぼす重要性を示唆している。Dentonら $(1981)^{4)}$ は Deardorff らの実験観察をもとに対流層上端 での連行過程を組み込んだ対流混合層のモデル化を行っ ている.

一方, 熱塩対流に関する研究の流れは大きく2つに分 けられよう.1つは二重成層場の安定・不安定問題に関 する研究であり, Baines \& Gill $(1969)^{5)}$ の研究を始め として種々の二重成層に対する安定限界条件が得られて いる．他の1つは混合過程に関するものである．Turner $\left.(1965)^{6}\right)$ は塩分二成層界面での熱・濃度の輸送量を 定量的に評価した. Shirtcliffe $(1968)^{71}$ は線形分布を有 する塩分濃度成層を底面から加熱する実験を行い, Rayleigh-Taylor 不安定の断続的な発生によって多段階 密度構造が発達していく過程を実験的に明らかにしてい る. Huppert ら $(1979)^{8)}$ は以上の成果を組み入れた解 析モデルを開発している.玉井ら $(1982)^{91}$ は貯水池の 濁度成層化を想定して熱-濁度成層場で生ずる混合過程 を熱一塩の場合と比較し本質的に両者に差異のないこと を示す之同時に，対流層の発生条件等に関し興味ある成 果を得ている. Delnore $(1980)^{(0)}$ は海洋混合層の数值乇 デルに熱塩対流効果を組み入れることによって予測結果 が改善されることを示している.

\section{(3) 本研究の概要}

著者らは先に，任意の温度・濃度分布を有する:重成 層場での対流発生限界を理論的に誘導し、模型実験に

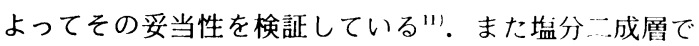
の熱対流の実験において界面変動の特性を明らかにし， 連行速度の定量的評価を行っている”（以下文献 11) を論文-I と記す). 本研究は以上 2 つの成果を基盤とし て底面から加熱された塩分二成層場および連続成層場で の熱対流混合過程の変遷に関する数値解析を行い, 実験 結果との比較検討を行うとともに成層場のエネルギー収 支に関する考察を加えたものである.

2.においては実験方法と条件を記す.

3.では一層系での対流混合を論ずる.まずエネルギー 方程式から多層系での対流代表速度を誘導し，これを: 層系に適用して連行係数とリチャードソン数の関係を明 らかにする. 実験より得られた連行量・抎散量の輸送則 から,上・下層の温度・濃度・体積の経時変化を再現し, 実験値との比較によって輸送則の妥当性を検証する.
4.では連続成層系での対流混合を論ずる．任意の分 布形状を呈する二重成層場の安定限界条件と二層系での 輸送則をもとにして，線形および一般的な分布形を有す る連続濃度場の鉛直混合過程を推定し実験結果との比較 を行う。また熱エネルギーが鉛直混合を経て場のポテン シャルエネルギーへと移行する過程についての考察を行 う.

5.では本研究で得られた成果を要約し著者らの見解 を付す。

\section{2. 実験方法および実験条件}

実験水槽は図一1に示すように横 $20 \mathrm{~cm}$, 奥行 $8 \mathrm{~cm}$, 高さ $40 \mathrm{~cm}$, 側壁厚さ $2 \mathrm{~cm}$ の透明アクリライト製鉛直 一次元水槽である。正成層は所定水深の淡水の底部に塩

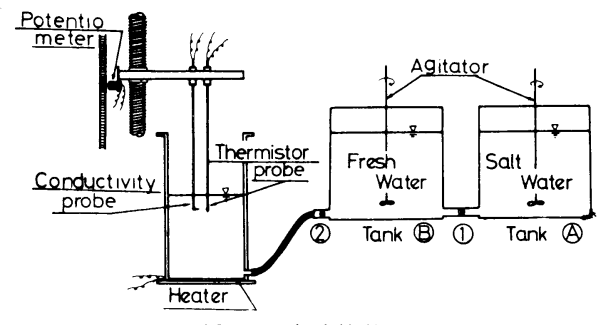

図一1 実験装置

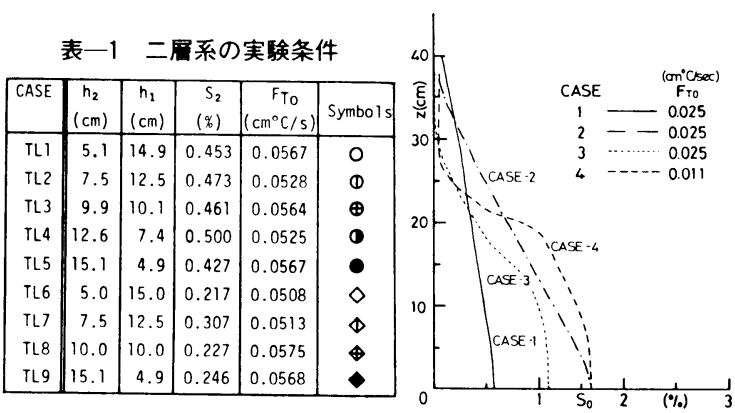

図一2 連続成屏場の実験に用い た初期漕度分布 $S_{0}(z)$ と 底面加熱度 $\boldsymbol{F}_{T 0}$

水を徐々に流入させることによって作製される，連続成 層は壏水・淡水供給水槽のバルブ開度を適宜調節し混合 濃度が連続的に変化したものを流入させることによって 所定の分布形が作製される。熱対流はいずれの場合も水 槽底面に設置したシリコンラバーヒーターによって発生 させる. 温度・塩分濃度はおのおのサーミス夕および電 導度計を用いて測定しその鉛直分布形を連続記録する。

表一1 に二層系の実験条件を示す (論文- I の再表示). 図一2に連続成層系の初期濃度分布 $S_{0}(z)$ および底 面加熱度 $F_{T 0}$ を示す.

\section{3. 塩分二成首場における熱対流過程}

熱塩対流の特徵は一様に混合した対流層と明瞭な密度 
境界面が形成される点にある。したがって, 熱・濃度の 鈆值輸送量は境界面で,の輸送量を把握することによって 評価される．ここではその単純化された場として二成層 場を対象とする。

\section{（1）対流層代表速度の評価}

対流による鉛直輸送量を評価するためには対流層の長 さ・速度に関する代表スケールを規定しなければならな い. 一様に混合した対流層に対しては層厚が長さスケー ルとして適していよう。速度スケールとして論文- I に おいては，簡単なエネルギ一的考察のもとに二層系での 対流代表速度の導出を試みた。本節では一般性を失わず， 後章の議論に拡張できるように，図一3に示す多段階対

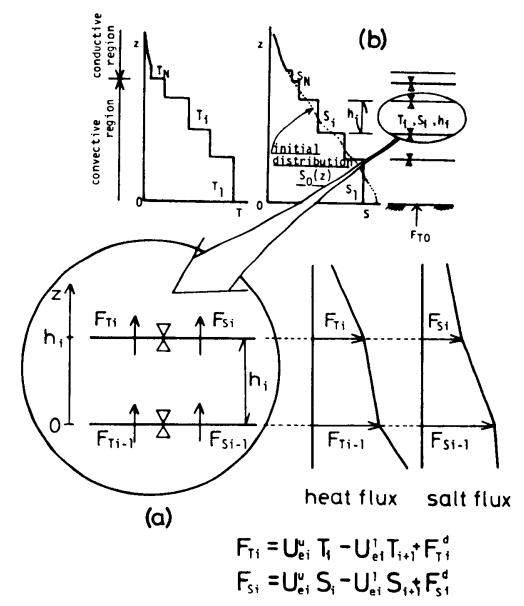

図一3 多層系および対流首の模式図

流層内の代表速度を成層場のエネルギー方程式から導出 する. 同図中 $h_{i}$ は下から第 $i$ 番目の対流層の層厚, $F_{T i}$, $F_{s i}$ はおのおの密度界面での熱および濃度フラックスで ある. 各物理量の鉛直方向の変化のみ考慮して温度・濃 度および乱れ運動エネルギーに関する保存則はおのおの 次のようになる.

$$
\begin{aligned}
& \frac{\partial T}{\partial t}+w \frac{\partial T}{\partial z}+\frac{\partial}{\partial z}\left(\overline{w^{\prime} T^{\prime}}\right)=\varkappa_{T} \frac{\partial^{2} T}{\partial z^{2}} \\
& \frac{\partial S}{\partial t}+w \frac{\partial S}{\partial z}+\frac{\partial}{\partial z}\left(\overline{w^{\prime} S^{\prime}}\right)=\chi_{S} \frac{\partial^{2} S}{\partial z^{2}} \\
& \frac{\partial}{\partial t}\left(\frac{c^{2}}{2}\right)=-\overline{u^{\prime} w^{\prime}} \frac{\partial u}{\partial z}-\frac{\partial}{\partial z}\left[\overline{w^{\prime}\left(\frac{p^{\prime}}{\rho}+\frac{c^{2}}{2}\right)}\right] \\
& -\frac{\overline{w^{\prime} \rho^{\prime}}}{\rho_{0}} g-\varepsilon
\end{aligned}
$$

また，状態方程式は

$$
\rho=\rho_{0}(1-\alpha T+\beta S)
$$

である.ここに $t$ は時間, $z$ は鉛直方向坐標, $\rho \cdot \rho_{0}$ は おのおの密度およびその基準値, $p$ は圧力, $u \cdot w$ は水 平・鉛直方向流速, $T \cdot S$ は温度・濃度であり, prime
はこれらの変動量であることを示す， $\alpha \cdot \beta$ はおのおの温 度・濃度を密度に換算する係数， $\boldsymbol{x}_{T} \cdot \boldsymbol{x}_{S}$ はおのおの熱・ 濃度の拡散係数, $c^{2}=\overline{u^{\prime 2}+w^{\prime 2}}, g$ は重力加速度, $\varepsilon$ は 逸散量, 一は時間平均操作を意味する.

ここで以下のような仮定を設ける.

（ｉ）各対流層内では一様に混合しておりその温度・ 濃度をそれぞれ $T_{i}, S_{i}$ とする. また分子拡散は無視で きる. すなわち, $\partial T / \partial z=\partial S / \partial z=0, \quad \partial T_{i} / \partial t=$ $d T_{i} / d t, \quad \partial S_{i} / \partial t=d S_{i} / d t, \quad x_{T}\left(\partial^{2} T / \partial z^{2}\right)=x_{S}$ $\left(\partial^{2} S / \partial z^{2}\right)=0$ が成立する.

(ii ) 乱れエネルギーの時間変化率は小さく $(\partial / \partial t)$. $\left(c^{2} / 2\right)=0$ とおける.

（iii） 速度せん断はない。 $\partial u / \partial z=0$.

以上の仮定を用いてまず式（1），（2）を図一3に示 す境界条件のもとに積分すれば次式が得られる。

$$
\begin{aligned}
& \overline{w^{\prime} T^{\prime}}=\left(F_{r i}-F_{r i-1}\right) z / h_{i}+F_{r i-1} \\
& \overline{w^{\prime} S^{\prime}}=\left(F_{s i}-F_{s i-1}\right) z / h_{i}+F_{s i-1}
\end{aligned}
$$

したがって対流層内の熱・濃度輸送量は図一3(a) に示 すように直線分布を呈する.一方, 式(4)を用いて式(3) を混合層内で積分すれば次式が得られる.

$$
\begin{aligned}
& {\left[w^{\prime}\left(\frac{p^{\prime}}{\rho_{0}}+\frac{c^{2}}{2}\right)\right]_{0}^{h_{i}}+\int_{0}^{h_{i}}\left(\beta \overline{w^{\prime} S^{\prime}}-\alpha \overline{w^{\prime} T^{\prime}}\right) g d z} \\
& \quad+\int_{0}^{h_{i}} \varepsilon d z=0 \ldots \ldots \ldots \ldots \ldots \ldots \ldots \ldots \ldots \ldots \ldots \ldots \ldots \ldots \ldots \ldots \ldots
\end{aligned}
$$

ここでエネルギーの発生量と逸散量は対流運動エネル ギーに比例する— $(G+D) \propto u_{f i}^{3}$ 一仮定し ${ }^{12)}$ 式 ( 7 ) に式（5)，（6）を代入すれば対流層代表速度 $u_{f i}$ は次 式のように求められる.

$$
u_{f i}^{3}=C\left[\left\{\alpha\left(F_{T i}+F_{T i-1}\right)-\beta\left(F_{S i}+F_{S i-1}\right)\right\} g h_{i}\right] \cdots \cdots(8)
$$

ここで，Cは定数であり熱対流での速度スケールとの 対忘性を勘案して $C=1$ とおく. 式（8）は4.におい て連続成層系での鉛直対流の評価に際し必要となる.

式（８）を二層系に適用すれば上・下層内の対流代表 速度はおのおの次式のようになる.

$$
\begin{array}{ll}
u_{\Omega 1}=C .\left[\left\{\alpha\left(F_{T 0}+F_{T_{1}}\right)-\beta F_{S_{1}}\right] g h_{1}\right\}^{\frac{1}{3}} & \text { (下層) } \cdots(9) \\
u_{\Omega 2}=C .\left[\left(\alpha F_{T 1}-\beta F_{S 1}\right) g h_{2}\right]^{\frac{1}{3}} & \text { (上層) } \cdots(10)
\end{array}
$$

ここで $F_{T 0}$ は底面からの熱供給量 $\left(\mathrm{cm}^{\circ} \mathrm{C} / \mathrm{s}\right)$ である. $u_{s 2}$ に関しては論文- I と同じであり $u_{\Omega}$ については多 少異なる結果である. 上式は浅技らが求めた結果 ${ }^{(3)}$ と等 価なもの之なる.

\section{(2) 連行係数}

図一3 中の第 $i$ 番目対流層内の体積 $\cdot$ 温度 - 濃度に関 する保存式は次式のように表わされる.

$$
\frac{d}{d t}\left[\begin{array}{c}
h_{i} \\
h_{i} T_{i} \\
h_{i} S_{i}
\end{array}\right]=
$$




$$
\left[\begin{array}{l}
U_{e i-1}^{u}-U_{e i}^{u}-U_{e i-1}^{l}+U_{e i}^{l}, \\
U_{e i-1}^{u} T_{i-1}-U_{e i}^{u} T_{i}-U_{e, i-1}^{l} T_{i}+U_{e i}^{l} T_{i+1} \\
\quad+F_{T i-1}^{d}-F_{T i}^{d}+F_{T 0} \delta_{i 1}, \\
U_{e i-1}^{u} S_{i-1}-U_{e i}^{u} S_{i}-U_{e i-1}^{l} S_{i}+U_{e i}^{l} S_{i+1} \\
\quad+F_{S i-1}^{d}-F_{S i}^{d} .
\end{array}\right]
$$

ここで $d / d t$ は時間微分, $U_{e i}^{u} \cdot U_{e i}^{l}$ は第 $i$ 界面でのお のおの上方向 ·下方向連行速度, $F_{T i}^{d} \cdot F_{S i}^{d}$ はおのおの分 子拡散による熱・濃度フラックス， $\delta_{i 1}$ はクロネッカー デルタを表わす。上式を一層系に適用し層厚・温度・濃 度の実測傎から上・ 下方向連行速度 $U_{e}^{u} \cdot U_{e}^{l}$ を求めた結 果の一例を図一 4 に示す。底面からの熱浮力供給によっ て界面での静的安定度 $R_{\rho}=\Delta \rho_{S} / \Delta \rho_{T}\left(\Delta \rho_{T}\right.$ は界面での 温度密度差, $\Delta \rho_{s}$ は濃度密度差）が減少し界面変動が増 大する結果, 図に示すように連行速度が時間とともに急 激に増大する. 以上のように求めた $U_{e}^{u}, U_{e}^{l}$ を式 (9), （10）の代表流速 $u_{\Omega}, u_{\Omega 2}$ を用いて無次元化し連行係数 $E^{u(l)}=U_{e}^{u(l)} / u_{\boldsymbol{N}(2)}$ とリチャードソン数 $R_{i}^{u(l)}=\varepsilon g h_{i} / u_{f i}^{2}(\varepsilon$ $\left.=\left(\Delta \rho_{s}-\Delta \rho_{\tau}\right) / \rho_{0}\right)$ の関係しして整理したものが図一5で
ある、 $u_{52}$ に関する図一5(a) は論文一Iの再図化である。 図一5(b) についても值および傾问ともにほとんど差簧 はなく論文-Iで論じた界面変動特性に関する結果に本 質的な変化は寺えない.

図一5(a), (b) の最碓值としてほぼ次式の関係を得る. $E=U_{e} / u_{f_{i}}=0.02 R_{i s}^{-1}$

ここで熱対流による混合効果と機械的擾乱である程に よる泚令効果を比較することは, 泚合現象のモデル化と

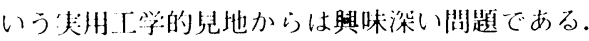

そこで塩分…層系での風による鈆消潉合に関する $W_{u}$ （1973）の実験結果 ${ }^{14}$

$$
U_{e} / u_{*}=0.234 R_{i *}^{-1}
$$

と式 (12) の比較を行う. .上式中, $R_{i *}=\varepsilon g h / u_{*}^{2}$ は摩 擦速度 $u_{*}$ に関するリチャードソン数である。式 (12), (13) から求められる $U_{e}$ をそれぞれ等置して対流速度 $u_{s}$ と摩擦速度 $u_{*}$ 間の換算係数 $\eta=u_{s} / u_{*}$ を求めれば $\eta$ $=2.3$ が得られる。これはZeman ら $(1977)^{151}$ が半理論 的に求めた值ときわめてよく一致しており，また

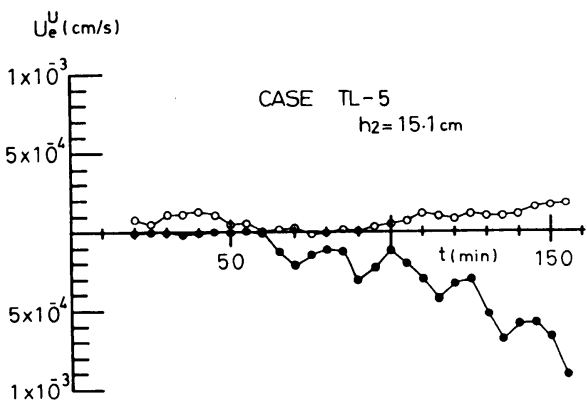

$U_{e}^{L}(\mathrm{~cm} / \mathrm{s})$

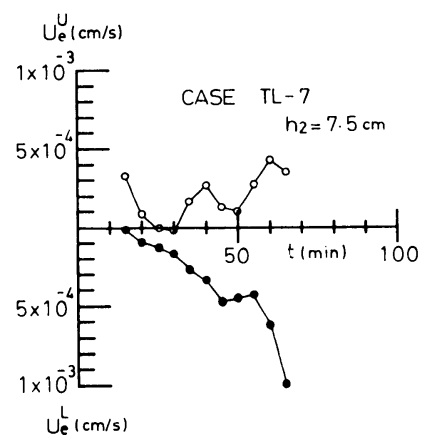

$U_{e}^{L}(\mathrm{~cm} / \mathrm{s})$

図一4 連行速度の時間变化の例 (Case TL-5, 7)

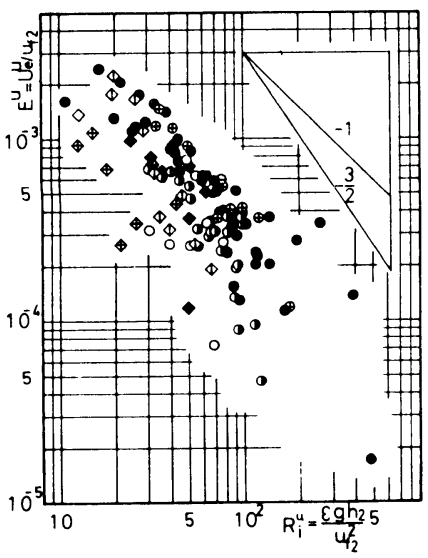

(a) 上向き連行

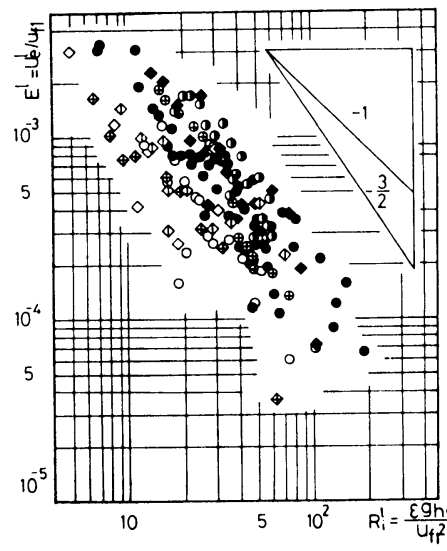

(b) 下向き連行

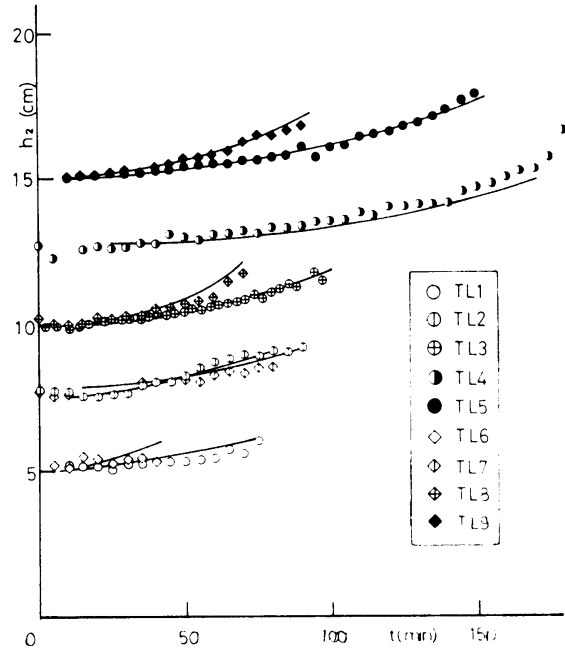

図一6 界面位羁の時闰的变化 
$u_{*}$ に比べて 2 倍強の混合能力を有することを示し, 興 味深い結果である.

\section{（３）熱塩二届系での鉛直混合過程の推定}

熱塩成層界面では連行に加えて拡散による輸送過程が 存在する。これは実験より，連行速度之同時に算出され， 次式のように表わされる"'.

$$
\begin{aligned}
& F_{r i}^{d} / F_{T p}=\left\{\begin{array}{ll}
\frac{4.9\left(R_{p i}-1\right)}{R_{p i}-0.59} R_{p i}^{-2.8} & \left(1 \leq R_{p i} \leq 2.8\right) \\
4.0 R_{p i}^{-2.8} & \left(2.8 \leq R_{p i}\right)
\end{array}\right\} \cdots \\
& \beta F_{s i}^{d} / \alpha F_{r i}^{d}=0.15
\end{aligned}
$$

ここで $F_{T \rho}$ は界面と闰じ温度差を有する伝導板での熱 フラックスの理論值である.

本節では式 (12)，(14）で与えられる輸送則を式 (11) に適用して, まず二層系での変遷過程を再現し, 実験値 との比較を行うことによって輸送則の精度と妥当性を確 忍する。ほぼ明瞭な密度境界面が形成された時刻の諸量 を初期値として式 (11) を数值積分する.

図一6は界面位置 (下層厚さ), 図一7は上・下層の温 度 $T_{i}$, 濃度 $S_{i}, \quad(i=1,2)$, 図一8 は界面での温度密度 差 $\Delta \rho_{T}$, 濃度密度差 $\Delta \rho_{S}$, ならびに界面での静的安定度 $R_{o}=\Delta \rho_{S} / \Delta \rho_{T}$ の時間変化をそれぞれ示す. 図中, 各記 岇が実験优，各曲線が計算による再現值である. 成層浸 食による界面位置の変化は連行輸送量のみによって, 温 度・濃度の変化は連行と拡散輸送量の屾老によってもた

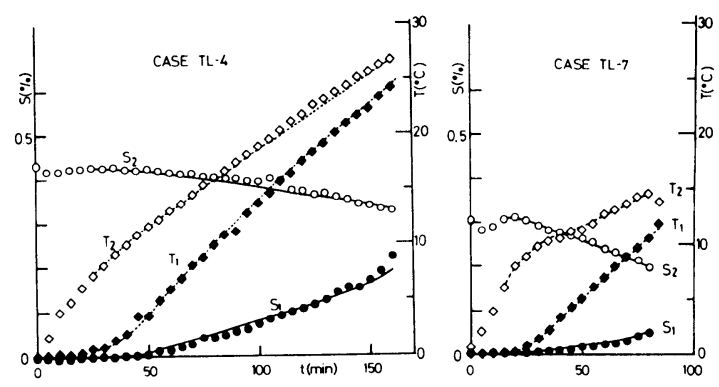

図一 上 ·下層内の温度 ・濃度の時間变化の例 $(T L-4,7)$

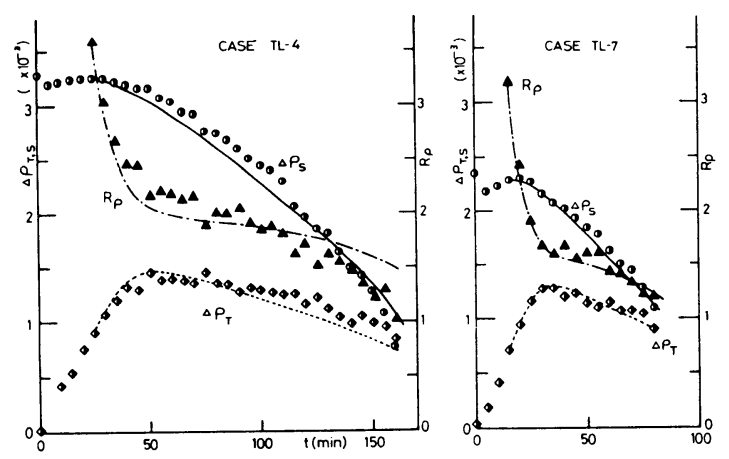

図一8 界面での温度密度差 $\Delta \rho_{T}$, 浱度密度差 $\Delta \rho_{s}$, 界面安定度 $\boldsymbol{R}_{o}=\Delta \rho_{S} / \Delta \rho_{T}$ の時間变化の例（Case TL-4, 7)
らされるが, そのいずれもが精度よく再現されている. これより熱塩密度境界面においては式（12）の連行量と 式（14）の拡散量という2つの輸送過程から成るという 輸送則の妥当性が裏づけられる.

\section{4. 連続濃度成層場における熱対流過程}

二層系での混合現象に関する知見と二重成層場での安 定性解析に関する成果をもとに連続成層場での鉛直混合 について論ずる．実験は二層系の場合と同様に底面から 安定な成層を加熱することによって行う. 実験条件は図 一2に示されたように，従来対象とされてきた一定の濃 度勾配をもつ線形密度場に加えて, 半水深付近に 1 つの 変曲点を有する $\tanh$-型関数形の濃度場を対象とする. 後者は水深方向に勾配が変化する点と線形密度場に比へ てより安定な分布形である（ポテンシャルエネルギーが 大きい)という特徵をもつ・般的な濃度場として設定さ れた。

\section{（1）数值解析法}

連続成層系を底面加熱した場合に形成される多段階密 度構造を図一3(b) のように理想化してその発達を論じ た Huppert ら (1979) の混合層モデル に対し, 著者ら の研究成果および本研究独自の修正を加えて成層場の混 合過程の推定を行う. Huppert らのモデルは図一3(b) に示すように対流層群から成る階段状構造部とその上方 の熱拡散領域とから成り，これらの境界である対流層上 端部において密度ジャンプが 0 すなわち

$$
\Delta \rho_{N}=\beta\left\{S_{N}-S_{0}\left(d_{N}\right)\right\}-\alpha T_{N}=0
$$

という条件を課して熱塩成層場の発達を推定するもので ある.ここで $d_{N}=\sum_{i=1}^{N} h_{i}$ は対流層上端の高さである. 本 章で述べる数値計算法はこれに加えて以下の設定を行 う.

（｜）各密度境界面に式(12), (14)の輸送則を導入し, 式（11）を各層に適用して層厚・温度・濃度の時間的変 化を計算する。連行速度は拡散輸送量を式（14）によつ て求めた後, 式 (12) を $i=1, N-1$ の各界面で連立さ せて解くことにより得られる。対流層代表速度としては 式（8）を用いる.

(ii ) 対流層上方の領域の温度変化は熱抎散方程式を 解いて得られ, 濃度は初期の値を保つとする. 温度場が 次式で与えられる限界条件を満足したとき，新たな対流 層が最上対流層直上に瞬時に形成されるとする.

$$
\lambda=R_{T} / R_{T c} \geq 1
$$

ここで $R_{T}, R_{T C}$ は図一 9 に示すように熱拡散領域内の 安定性を吟味する範囲 $d$ に対する温度レイリ一数とそ の限界値であり，それぞれ次のように与えられる”!。

$$
R_{T}=\alpha \Delta T g d^{3} / \varkappa_{T} \nu
$$




$$
\begin{aligned}
R_{T C}= & \frac{\left.\left(1+\tau / P_{r}\right)<\sin ^{2} \pi z_{1} \cdot g\left(z_{1}\right)\right\rangle}{\left.\left(1+1 / P_{r}\right)<\sin ^{2} \pi z_{1} \cdot f\left(z_{1}\right)\right\rangle} \cdot R_{S} \\
& +\frac{27\left(P_{r}+\tau\right)(\tau+1) \pi^{4}}{\left.8 P_{r}<\sin ^{2} \pi z_{1} \cdot f\left(z_{1}\right)\right\rangle} \ldots \ldots \ldots \ldots
\end{aligned}
$$

ここで, $\nu$ は動粘性係数, $\Delta T(d), \Delta S(d)$ はおの おの $d$ に対応する熱拡散域での温度差および濃度差， $\tau$ $=x_{S} / x_{T}$ はルイス数, $\sigma=\nu / x_{T}$ はプラントル数, $z_{1}=z /$ $d$ は無次元鈆直方向座標, $f\left(z_{1}\right)=-(d / \Delta T) \cdot\left(d T / d z_{1}\right)$ は無次元温度勾配, $g\left(z_{1}\right)=-(d / \Delta S) \cdot\left(d S_{0} / d z_{1}\right)$ は無 次元濃度勾配, $R_{S}=\beta \Delta S g d^{3} / \kappa_{S}$ レは濃度レイリー数で ある. また $>>=\int_{0}^{1} d z_{1}$ である。

（iii） 発生した対流層の厚さの初期值は $R_{T}=R_{T C}$ を 満足する $d$ に等しいとし, その温度・濃度はそれぞれ 次式で与えられる.

$$
\begin{aligned}
& h_{N+1}=d, \quad T_{N+1}=\frac{1}{d} \int_{d_{w}}^{d_{N}+d} T(z) d z \\
& S_{N+1}=\frac{1}{d} \int_{d_{w}}^{d_{n}+d} S_{0}(z) d z
\end{aligned}
$$

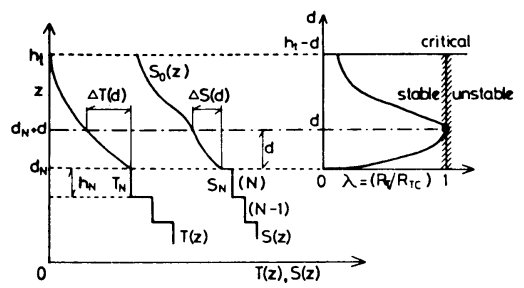

図一9 不安定限界時の $\lambda=\boldsymbol{R}_{T} / \boldsymbol{R}_{T c}$ と $\boldsymbol{d}$ の説明図
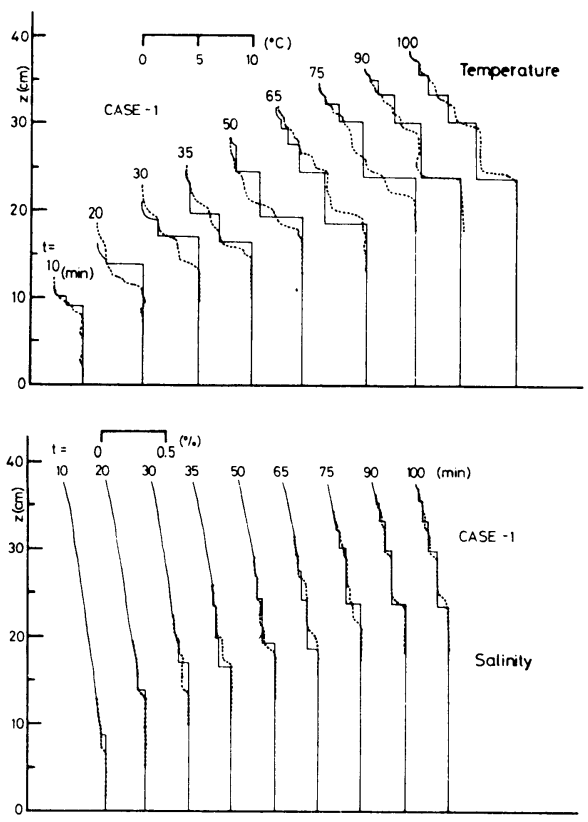

(a) Case 1

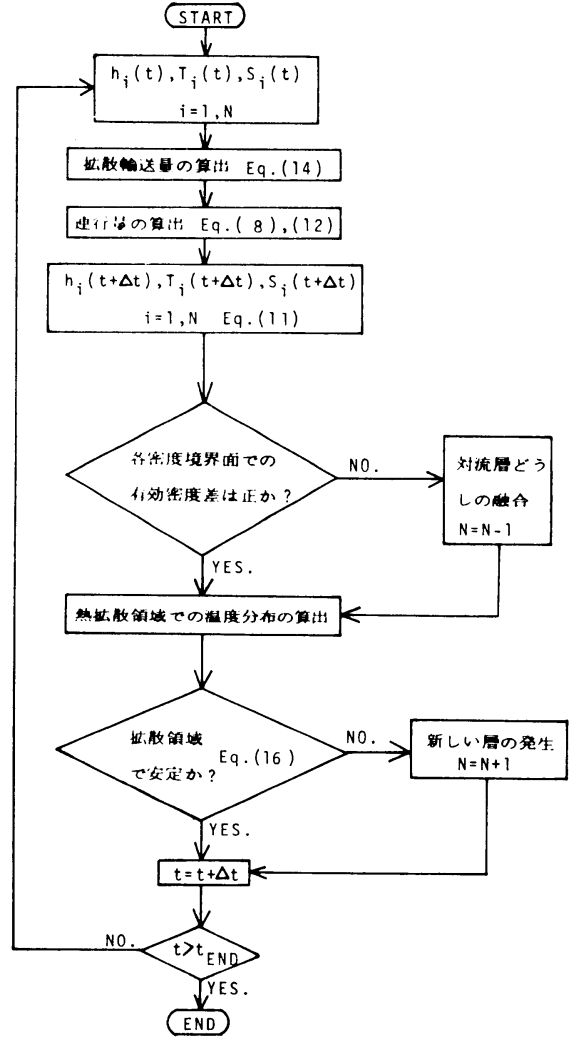

図一10計算の流れ図
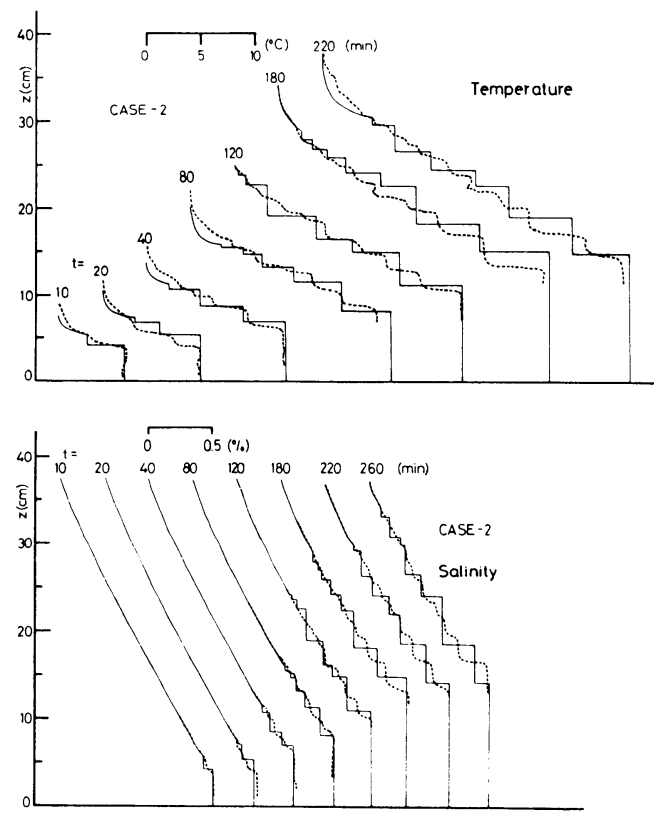

(b) Case 2

図一11 温度 ・湿度分布の時間的变化 (線形濃度分布場命) 

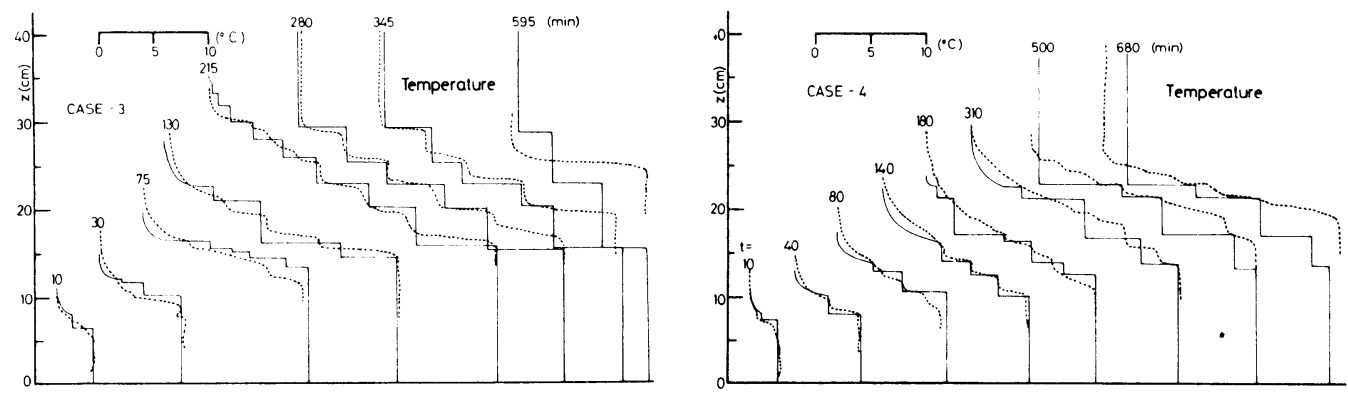

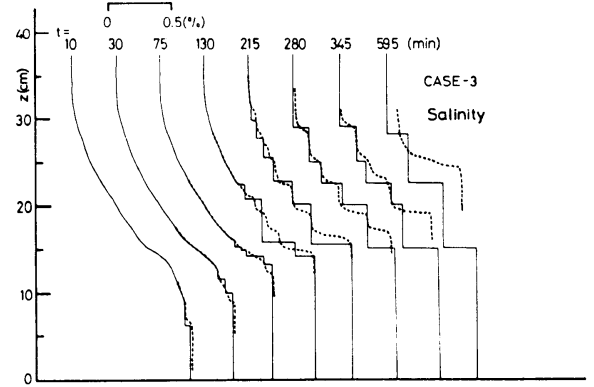

(a) Case 3

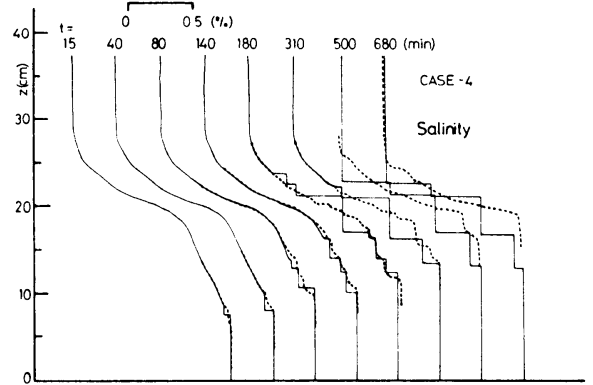

(b) Case 4

図-12 温度・䝶度分布の時間的変化 (変曲点を有する場命)

以上の設定のもとに各対流層の保存式と熱拡散方程式 をそれぞれ数値積分していけば, 熱塩成層場の発達を推 定することができる. 図一10に計算の流れ図を示す.

\section{（2）実験結果と計算結果の比較検討}

図一11は初期濃度分布がほぼ一定勾配を有する場合 (Case 1，2) の温度 ・濃度分布の時間的変化を, 図一 12 は変曲点をもつ場合（Case 3，4）のものを示す. い ずれも点線が測定值, 㬰線が数值計算值である. なお密 度境界面には対流層厚の 0.1 倍のオーダーの波高を有す る内部波が絶えず生長しており ${ }^{11}$, 同図中に示す実測值 はこの程度の変動も反映した鉛直分布形の瞬間值であ る.

まず線形濃度場のケースにおいては Case 1, 2 とも 加熱度はほぼ等しいが, 初期濃度勾配はCase 1 におい て, より小さいため対流層上端の上昇がより早く, また 全層混合に至るまでの時間は短いことがわかる.下方の 層では密度境界面での有効密度差が減少するため対流層 よ゙うしの融合を繰り返しながら層厚が増大する.

一方，変曲点を有する Case $3 ， 4$ においては対流層 上端が中央の密度変曲点付近に達すると発達速度が減退 し, 下部層での蓄熱量が増加する. 変曲点付近では濃度 公配が最大であるため, 温度による不安定密度勾配は式 (16)（18）で与えられる不安定限界に至るまで増加し 続ける.この場合, 熱昖散域においては温度・濃度分布 ともに曲率が大きくなるため線形分布を仮定した従来の 安定性解析では対流層発生を正確に評価することはでき
なくなる。これに対し，本解析では温度・濃度分布形を 考慮に入れた限界条件を用いることによって, 変曲点付 近から水槽上端に至るまでの大きな対流層の発生が実験 值とよく対忍して再現されている. 全水深にわたって対 流層が形成された後は, 層数がしだいに減少してゆき濃 度勾配最大值付近において 1 つの界面が残り, 二層系が 形成されることが実験值よりわかる．同図には示さない が, その後, 二層系の実験と全く同様の変遷過程をたど り，最終的には全層一様に混合する。

いずれのケースも奏験値については鈆淔上方に向かう ほど, 視覚的には界面の存在が浔められるものの, 分布 形に現われる階段構造が不明瞭となる.これは上部の対 流層では温度差と層厚が小さいため, 層内が十分一様に 混合されるほど対流運動が活発ではないことに起因して いると考えられる.これに対し, 計算モデルにおいては 各対流層の規模にかかわらず，すべての層に対して二層 系での輸送則を適用しているため, 計算值と実験値との 差異が上方において特に大きいと考えられる. 以上のよ うなモデルの適用限界があることから多層系においても 二層系と同じ程度の精度で混合垷象を再現することは困 難であろうが, 対流層厚・温度・濃度のいずれについて も比較的正しく推定されているといえよう.なお, Case 3，4の後半において夷験值と計算值の適合度が少 る理由としては, Case 1, 2 に比べて長時間の実験であ るため, その間所定の実験条件に制御することが困難と なり側壁・上端からの熱損失の評価が時間とともに不正 

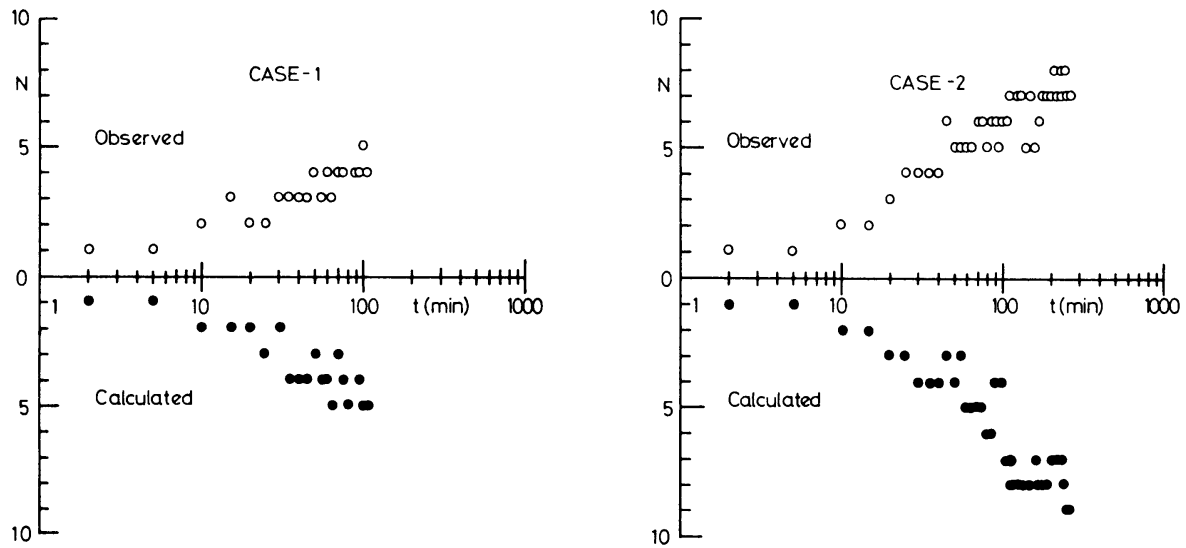

図一13対流居数の時間的变化 (線形濃度分布の場合)

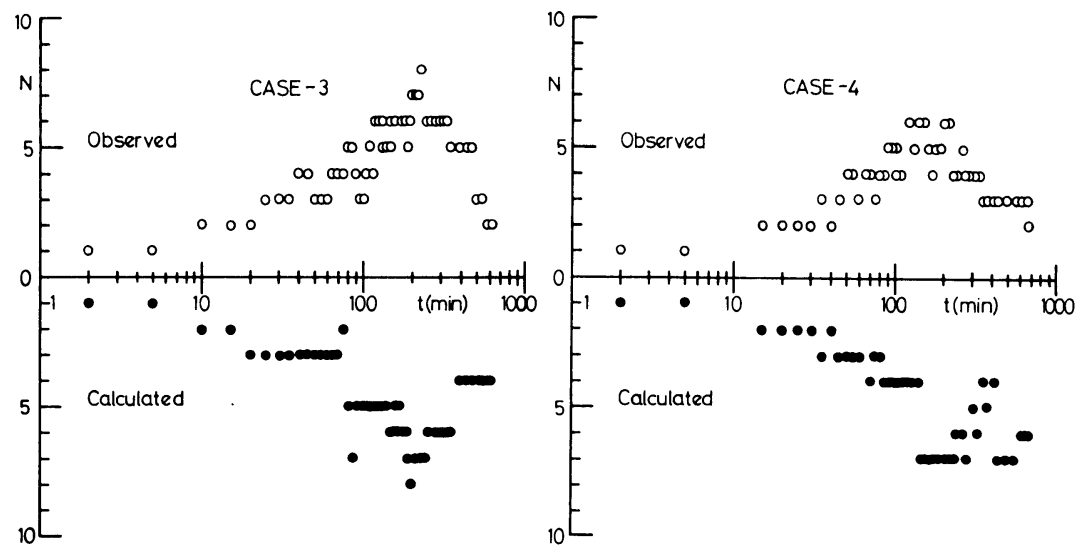

図一14 対流首数の時間的変化（変曲点を有する場合）

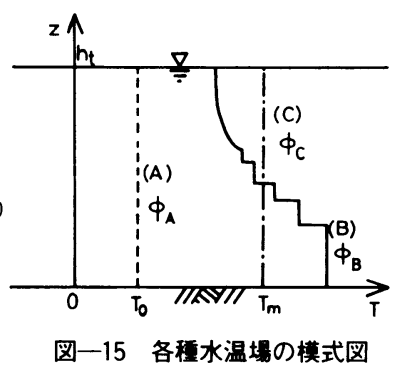

( A : 熱供給開始前の初期一样温度場, $\mathrm{B}$ ：成層形成後の水温場, $\mathrm{C}: \mathrm{B}$ の状 態を断熱過程で完全混合した一樣水 温場)
確になることが考えられる.

図一13，14 は対流層数の時間的変遷である. 白抜き の記号が実験値, 黒塗りの記号が計算値を示す. 層数は, 熱拡散域での不安定に続く対流層の発生によって増加 し, 対流層どうしの融合によって減少する（図一10参 照). 対流層の発生頻度と融合頻度はともに実験値と計 算値でよく対応しており, 安定限界条件と熱塩輸送則と がそれぞれ妥当であることが認識される．初期濃度分布 が線形の場合には Huppert ら $(1979)^{81}$ が示したように ほぼ時間の $1 / 2$ 乗に比例して層数が増大する. 変曲点を 有するCase 3, 4 においては対流層上端が水槽上端に 達した後も実験を継続している.この場合, 新たな対流 層が発生することはなく, 対流層の融合の繰り返しに よって層数が減少する.

Huppert らの数值計算では計算值と実験值が合うよう に輸送量と安定限界值を定めているため任意性を含む が, 本モデルでは連行過程を考虑した輸送則および分布 形を考虑した安定限界值をそのまま用いてあらゆる分布
形に対する変遷をより正しく推定することが可能となっ た.

（３）熱塩成層場のポテンシャルエネルギー

温度密度と濃度密度がもたらす成層場のポテンシャル エネルギー (以下，P.E. と略す) をそれぞれ評価し， 系外から供給された熱的内部エネルギーがいかなる推移 を経て成層場の P.E. として蓄えられるかを考察する.

温度・濃度・体積の保存を考慮すれば，加熱開始前の 状態からの温度密度場の P.E. の増分 $\Delta \phi_{T}$, および濃 度密度場の P.E. の増分 $\Delta \phi_{s}$ はおのおの次式のように 定義される.

$$
\begin{aligned}
& \Delta \phi_{T}=\int_{0}^{h_{t}} \rho_{0} \alpha g\left\{T(z, t)-T_{0}\right\}\left(h_{t}-z\right) d z \\
& \Delta \phi_{S}=\int_{0}^{h t} \rho_{0} \beta g\left\{S(z, t)-S_{0}(z)\right\} z d z \cdots \cdots
\end{aligned}
$$

ここで $T_{0}$ は初期水温である. いま, 温度密度場に関 して図一15に模式的に示すような 3 つの状態, すなわ ち, A：熱供給開始前の初期一様水温場, B：成層形成 
後の水温場, C : B の状態を断熱過程で完全混合した一 様水温場, をそれぞれ想定し, 各状態での温度に起因す るP.E.を $\phi_{A}, \phi_{B}, \phi_{C}$ とおく.

定義より $\Delta \phi_{T}=\phi_{B}-\phi_{A}$ である。このうち,

$$
\begin{aligned}
\Delta \phi_{T_{1}} & \equiv \phi_{C}-\phi_{A}=\int_{0}^{h t} \frac{1}{2} \rho_{0} \alpha g T(z, t) h_{t} d z \\
& =\frac{1}{2} \rho_{0} \alpha g T_{m} h_{t}^{2} \ldots \ldots \ldots \ldots \ldots \ldots \ldots \ldots \ldots \ldots \ldots \ldots \ldots \ldots
\end{aligned}
$$

は熱供給に伴う平均温度の上昇による P.E.の増分で ある。したがって $\Delta \phi_{T}$ と $\Delta \phi_{T 1}$ の差

$$
\begin{aligned}
\Delta \phi_{T 2} & \equiv \Delta \phi_{T}-\Delta \phi_{T_{1}}=\phi_{B}-\phi_{C} \\
& =\int_{0}^{h_{t}} \rho_{0} \alpha g\left(\frac{h_{t}}{2}-z\right) T(z, t) d z .
\end{aligned}
$$

が温度成層化がもたらす不安定性の尺度となる。

\begin{tabular}{|c|c|c|c|c|c|c|c|}
\hline \multicolumn{4}{|c|}{ 热供給の形態 } & \multirow{2}{*}{$\frac{J \phi_{T 1}}{\mathrm{JE}}$} & \multirow{2}{*}{$\frac{\Delta \phi_{T_{2}}}{\text { 負 }}$} & \multicolumn{2}{|c|}{ 温度勾配の形態 } \\
\hline (1) & t: & 方加 & 熱 & & & 安 & 定 \\
\hline (2) & $F$ & 方炌 & 去 & 解 & 負 & 安 & 定 \\
\hline (3) & F & 方力 & 口歖 & 正 & 正 & 不 & 定 \\
\hline (4) & 上 & 方 & 命 & 負 & 正 & 不 安 & 定 \\
\hline
\end{tabular}

式 (22)，(23）からわかるように $\Delta \phi_{T 1}, \Delta \phi_{T 2}$ の正負 は熱供給の形態によって表一2のようになる. $\Delta \phi_{T_{1}}$ の

\section{表一2 熱供給の形態と温度場の安定性との関係}

正負にかかわらず(3), (4)の場合, すなわち $\Delta \phi_{T 2}>0$ の ときにだけ不安定温度勾配を形成する. $\Delta \phi_{T 1}$ は, 結局, 静的な P.E. の変化分で, $\Delta \phi_{T 2}$ は成層の安定性と混合 に直接関与する断熱的な P.E. の增分であるといえよ う.

本実験における $\Delta \phi_{T}, \Delta \phi_{T 2}$ および $\Delta \phi_{S}$ の時間的変遷 を図一16に示す，図中の曲線は前節での数值解析から 得られた值である.さらに図一16から予想されるエネ ルギーの推移過程の模式図を図一17に示す．同図中, 矢印の太さはエネルギ一移行量の大きさを概念的に表わ している.凷図の結果を総合すると以下のようである.

系外からの熱供給エネルギーの大半である $E_{1}$ は鉛直 混合に関与することなく，そのまま $\Delta \phi_{T 1}$ として蓄えら れる. 残りの部分 $E_{2}$ のうちの一部 $\varepsilon_{2}$ は対流運動エネル ギーという形を介して, 濃度場の P.E. の増分 $\Delta \phi_{s}$ に 変換される。しかし $E_{2}$ の中の多くの割合を占める $\varepsilon_{1}$ な る量は濃度成層の安'定効果のため, 混合に貢献すること を抑制され， $\Delta \phi_{T 2}$ として残存する.このことは図一16 に示されるように, 成層度が強いあるいは加熱度が弱い 実験ケースほど $\Delta \phi_{S} / \Delta \phi_{T 2}$ が小さいことからも裏づけら れる. その他, 対流運動エネルギーのごく一部 $\varepsilon_{3}$ は粘 性逸散を経て再び熱エネルギーに還元されようが，その

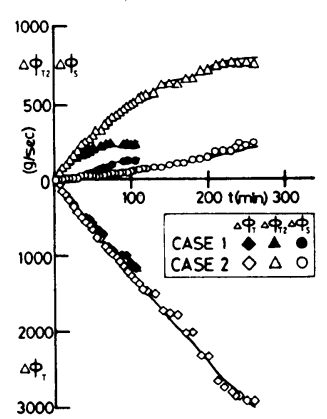

（a）線形濃度分布の場合

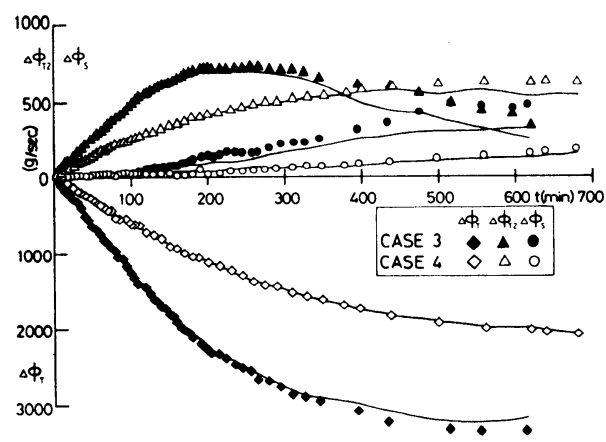

(b) 变曲点を伐する澧度分布心境们

図一16 各種ポテンシャルエネルギーの時間的变化

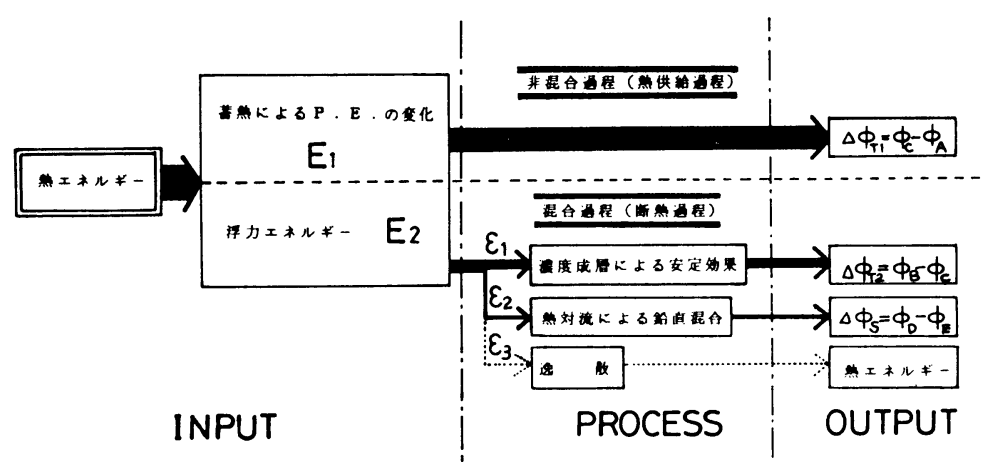

図一17 エネルギー推移過程の模式図 
量は僅少であると予想されしす。

以上のように熱的内部エネルギーの移行過程の大容が 理解されるとともに物質輸送に貢献するエネルギーの割 合が定量的に把握された。

\section{5. 結 論}

本論文は熱対流が誘因となる鉛直混合に伴う物質輸送 機構を調べるため, その 1 つの基礎的過程として鉛直一 次元熱塩対流を対象とし，二成層場と連続成層場での熱 対流過程を明らかにしたものである.

本研究で得られた主要な研究成果を要約すると以下の ようになる。

（1）成層場での乱れに関するエネルギー輸送方程式 から多層系の対流層内代表速度を求めた。これを用いて 熱塩二層界面での連行速度を無次元化し, リチャードソ ン数との関係を求めたところ論文-Iとほぼ同様の結果 を得た。

（2）熱塩一層系で得られた輸送則を用いて混合過程 の再現を行ったところ, 体積・温度および濃度のいずれ についても実験結果よのよい一致が得られた。これより 鉛㨁輸送量が連行輸送量と㹡散輸送量から成るとして怑 価された輸送則の妥当性が裏づけられた。

（３） “㕌系で心輸送則扩よび任意心温度・濃度分存

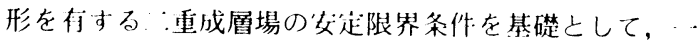
般的な分开形を有する連続濃度場での熱対流過程を推分 するモデル化を行った。その結果，溫度・濃度分布およ び層数についてほぼ夷験值を锐明し待る解析結果が得ら れた。

（4）滥度密度・濃度密度の変化に起肉するポテン シャルエネルギーをおのおの铗価することによって熱工 ネルギーが熱塩成層場のポテンシャルエネルギーへと推 移していく過程が理解された。また熱エネルギーのうち 物算輸送に使われる仕:事量が走量的に辞価された。

\section{参 考 文 献}

1) Turner, J.S. : Buoyancy effects in fluids, Cambride Academic Press, 1973, $367 \mathrm{p}$

2) Fischer, H. B., et al. : Mixing in inland and coastal waters, Academic Press, 1979, $478 \mathrm{p}$

3) Deadorff, J.W., G.E. Willis and B.H. Stockton : Laboratory studies of the entrainment zone of a convec. tively mixed layer, J. Fluid Mech., Vol, 100, pp. 41 64,1980

4) Denton, R. A. and Wood, I. R. : Penetrative convection at low Péclet number, J. Fluid Mech., Vol.113, pp. 1 21, 1981.

5) Baines, P. G. and Gill, A. E. : On thermohaline convec tion with linear gradients, J. Fluid Mech., Vol. 37, pp. 289 306, 1969.

6) Turner, J.S. : The coupled turbulent transport of salt and heat across a sharp density interface, Int. J. Heat Mass Transfer, Vol.8, pp. 759 767, 1965.

7) Shirtcliffe, T.G. L. : The development of layered thermosolutal convection, Int. J. Heat Mass transfer, Vol. 12, pp. 215 222, 1968.

8) Huppert, H.E. and Linden, P.F. : On heating a stable salinity gradient from below, J. Fluid Mech., Vol. 95, pp. $431 \sim 464,1979$.

9）进井信行・浅枝 隆・高橋由多加：熱的外乱により連続

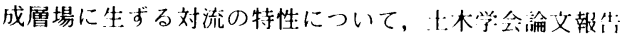
集，第 323 号, pp. 109 119, 1982.

10) Delnore, V.E. : Numerical simulation on thermo-haline convection in the upper ocean, J. Fluid Mech., Vol. 96, pp. 803 826, 1980.

11) Murota, A. and Michioku, K. : Stability and vertical mixing process in double-diffusive stratification system composed of heat-salt complex, J. Hydroscience and Hydraulic Engineering, Vol. 1, pp. 53－63, 1983. (棆义 l)

12) Kraus, E. B. : Modelling and prediction of the upper layers of the ocean, Pergamon Press, 1975, 325 p.

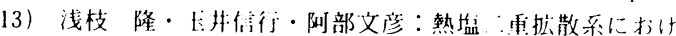

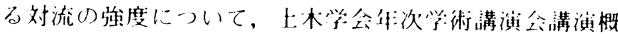
要集, 36, pp. 422 423, 1981.

14) Wu, J. : Wind-induced turbulent entrainment across a stable density interface, J. Fluid Mech., Vol.61, pp. $275 \sim 287,1973$

15) Zeman, O. and Tennekes, H. : Parameterization of the top of the daytime atmospheric boundary layer, J. Atmos. Sci., Vol. 34, pp. 111 123, 1977.

(1983.9.19·受付) 